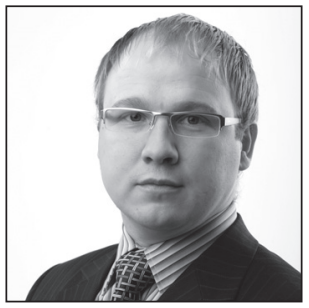

Anto Kasak

Mag. iur.

Attorney-at-Law

Partner, Kasak \& Missik Law Office

\title{
Special Treatment of the Floating Charge in Insolvency Proceedings
}

\section{Introduction}

The principle of pari passu, or equal treatment of the creditors in insolvency proceedings, is widely recognised in many countries. This is one of the key objectives for insolvency proceedings. The World Bank has found that ' $[t]$ hough country approaches vary, effective insolvency systems should aim to provide for equitable treatment of similarly situated creditors, including similarly situated foreign and domestic creditors'. ${ }^{{ }_{1}}$ This principle means that the creditors relevant to the insolvency proceedings should be treated equally in equal situations. Exceptions from the principle are as common as application of the principle itself, however. In most countries, a pledge-holder is preferred to other creditors with respect to the outcome of sale of the object of the pledge. This means that the outcome of the sold object of the pledge is not distributed among all creditors but received by the pledge-holder for the pledged object. Some authors go even further and say that this does not constitute a true exception to the pari passu principle, because the pledged object should not be part of the insolvency estate and satisfaction of the secured creditors should be regulated outside the realm of insolvency proceedings. ${ }^{{ }_{2}}{ }^{2}$ Nevertheless, business and society depend on an adequate system of credit and it is, therefore, necessary to ensure the adequate protection of secured creditors, to keep them lending. Consequently, the author considers it of utmost importance to avoid allowing other creditors to obtain dividends from the pledge sale before the secured creditor does.

The situation is more complex in the case of the floating charge, since it covers movable property of the debtor up to the amount of the charge. The author maintains that the floating charge is an easy, convenient, and flexible way to secure a claim while both protecting the creditor's interests and allowing the debtor to sell his property where necessary. On the other side, the floating charge covers almost all movable property of the debtor, which is sold in full to cover the claim. In such cases, the unsecured creditors end up left with nothing. Such a situation may amount to the unequal treatment of unsecured creditors. For this reason, the author concludes that, in contrast to regular secured creditors, less preferential treatment of the floatingcharge holders may be justified. The author suggests creating a system for distributing a fair amount of money to the unsecured creditors on the account of the floating-charge holder's fund.

\footnotetext{
World Bank. Principles and Guidelines for Effective Insolvency and Creditor Rights Systems. 2001, p. 76. Available at http:// www.worldbank.org/ifa/ipg_eng.pdf (most recently accessed on 23.3.2015).

$2 \quad$ R.M. Goode. Principles of Corporate Insolvency Law, second edition. London: Sweet \& Maxwell 1997, p. 152.
} 
Therefore, the aim for this article is to analyse whether the claim secured by a floating charge should be preferred fully in insolvency proceedings. If full preferential treatment of the claim secured by a floating charge is not justified, the question is this: to what extent should such claims be preferred?

Analysing the problem surrounding the priority limits of the floating charge in insolvency proceedings, the author presumes that the insolvency estate includes enough funds for the costs and expenses of the insolvency proceedings. The question of whether the secured creditor shall participate in covering the costs and expenses of the insolvency proceedings is another matter that is not covered by this article.

In addition to Estonian law, the author uses sources from English law, because the security instrument in question, the floating charge, has been widely analysed for a long time in the United Kingdom. German law does not recognise an instrument comparable to the floating charge encountered in English law. ${ }^{*}$ Therefore, claims cannot be secured by a floating charge in Germany and claims so secured cannot have priority in insolvency proceedings. Obviously, if German law does not recognise the concept of the floating charge, there cannot be any special regulation pertaining to the floating charge in the Insolvency Statute of Germany. ${ }^{*}$ The author will also analyse the laws of our neighbour states Finland and Latvia, because these states recognise the concept of the floating charge and our legal practice encompasses contact with these countries as our neighbours.

\section{Justification for the priority of the secured claim}

Secured claims are those secured by various pledges such as mortgage, lien and registered pledge, fixed charge, and floating charge. If the debtor fails to pay in time, the creditors are entitled to sell the pledged asset or have it be sold to cover the debt amount due. The pledge is highly important in the market economy, as it ensures satisfaction of a claim with a higher degree of probability. However, even having a secured claim does not relieve the creditor of all risks. For example, the market value of the pledge may be insufficient to cover the claim. The property encumbered by the pledge may suffer damage. Yet the author suggests that the pledge is the most reliable option for ensuring satisfaction of a claim.

All developed economies depend to a high degree on the availability of credit. ${ }^{*}$ Many insolvency laws recognise the rights of secured creditors to have first priority for satisfaction of their claims. ${ }^{*}$ Therefore, secured claims shall be satisfied before regular unsecured claims, which constitutes an exception to the pari passu principle. The infringement of one principle may be justified by other principles. According to another principle, security interests and other real rights created prior to the insolvency proceeding are unaffected by the winding up. This means that, in general, a creditor holding real rights, unaffected by the winding up, may proceed to realise his security or other right of property as if the company were not in liquidation..$^{7^{*}}$

Pursuant to the English law in force, the liquidation of a company generally does not affect a creditor's rights. The secured creditor is free to realise its security without reference to the liquidator. ${ }^{* 8}$ This means that the English insolvency system differs from the Estonian insolvency system in that the object of the pledge is not to be part of the insolvency estate and the pledged object is to be sold outside the insolvency proceedings. This is the reason Prof. Goode finds that preferring secured claims is not a true exception to the pari passu principle. ${ }^{*}$

3 A. Rahmatian. A Comparison of German Moveable Property Law and English Personal Property Law. Available at http:// www.iuscomp.org/gla/literature/rahmatian.htm\#sdfootnoteosym (most recently accessed on 21.3.2015).

4 Insolvency Statute of Germany. Available at http://www.gesetze-im-internet.de/englisch_inso/index.html\#gl_pooo7(most recently accessed on 21.3.2015).

5 World Bank. Report of Working Group on Debtor Creditor Rights. Available at http://web.worldbank.org/WBSITE/EXTERNAL/TOPICS/LAWANDJUSTICE/GILD/o,,contentMDK:20154449 menuPK:146222 pagePK:64065425 piPK:162156 t heSitePK:215006,0o.html\#1, material on debtor-creditor regimes (most recently accessed on 24.3.2015).

6 United Nations Commission on International Trade Law. Legislative Guide on Insolvency Law, p. 269. Available at http:// www.uncitral.org/pdf/english/texts/insolven/o5-80722_Ebook.pdf (most recently accessed on 19.3.2015).

$7 \quad$ R.M. Goode. Principles of Corporate Insolvency Law, 4th edition. London: Sweet \& Maxwell 2011, p. 96.

8 D. Faber et al. Commencement of Insolvency Proceedings. Oxford University Press 2012, p. 265.

$9 \quad$ R.M. Goode (see Note 2), p. 152. 
According to $\S 35$ of the Estonian Bankruptcy Act, ${ }^{*}{ }^{* 10}$ the debtor's assets become part of the bankruptcy estate upon the declaration of bankruptcy. This means that all assets of the debtor, including encumbered assets, become part of the bankruptcy estate. Section 135 stipulates that a trustee shall sell the bankruptcy estate pursuant to the procedure provided for in the Code of Enforcement Procedure, taking into account the specifications prescribed by the Bankruptcy Act. Pursuant to $\$ 153$ (2), the outcome of sold encumbered property shall be distributed only to the charge-holder, with one exception - a certain percentage, but not more than $15 \%$, shall be allocated to cover the costs and expenses of the insolvency proceedings. Therefore, under Estonian insolvency law, the pledged assets are part of the insolvency estate, which shall be sold by the trustee. The dividend from the sale of the encumbered property shall be distributed to the secured creditors. Although English law differs from Estonian law, the two systems have the same purpose. No other creditor than the charge-holder is entitled to receive the outcome of the sale of an encumbered item of property.

In the event of the pledged object being sold in the insolvency proceedings and the outcome being distributed in accordance with pari passu among all the creditors, the pledge-holder will not have any use of the pledge. This would cause uncertainty as to the securities in the insolvency proceedings, which would have a negative impact on the credit institution. The Cork Committee Report stated a conclusion that there is a direct link between every credit transaction and the financial health of the society. ${ }^{* 11}$ In consequence, the negative effect on the credit institution would harm the development of the market economy. The IMF has noted that, if a secured creditor is given the equivalent of first priority at the time of distribution (or directly receives the proceeds from the sale of collateral), the provision of secured credit is facilitated. ${ }^{{ }^{1}}$

Prof. Varul has summarised the problem as follows: 'Secured claims shall be preferred to unsecured claims, because otherwise the pledge as such would lose credibility, which would have a bad influence on the development and stability of the economic relations. ${ }^{, * 13}$ Therefore, limiting the pledge-holder's rights would discredit the economic system. Accordingly, we cannot do it and must prefer secured creditors to unsecured creditors.

For the reasons described above, a claim secured by a floating charge is a secured claim and should be preferred over unsecured claims. On the other hand, the floating charge differs from other securities in that the object of the floating charge is more uncertain than the object of other securities. This position is supported in the literature, where Richard Calnan finds that '[a]lthough the basic principle is that a secured creditor is entitled to the net proceeds of sale of the secured assets in order to discharge his debt, where the charge constitutes a floating charge certain categories of unsecured creditor rank ahead of the floating charge'. ${ }^{* 14}$ Therefore, a question arises as to whether the floating charge needs special treatment in insolvency proceedings.

\section{The distinctness of the floating charge from other charges}

Estonian insolvency law does not make any distinction between the floating charge and other charges with regard to the priority of the security in the insolvency proceedings. Secured claims, including the floating charge, have full priority under $\$ 153$ (1) of the Bankruptcy Act of Estonia. The situation is the same in the Republic of Latvia. The floating-charge holder is a secured creditor under the Latvian Insolvency Law's Section 7, Subsection $1{ }^{*} 15$ According to Sections 111 and 116, the administrator sells the pledged assets of the debtor and the holder of the floating charge has full priority in respect of the outcome of the realisation of the encumbered property.

10 Pankrotiseadus (Bankruptcy Act). - RT I 2003, 17, 95 (in Estonian).

11 Insolvency Law and Practice: Report of the Review Committee. London: Her Majesty's Stationery Office 1982, p. 12.

12 Orderly and Effective Insolvency Procedures: Key Issues. Legal Department of the International Monetary Fund 1999, p. 47.

13 P. Varul. Selgitavaid märkusi pankrotiseadusele (Explanatory commentary to the Bankruptcy Act). - Juridica 1994/1, p. 11 (in Estonian).

14 R. Calnan. Proprietary Rights and Insolvency. Oxford University Press 2010, p. 37.

15 Insolvency Law of the Republic of Latvia. Available at http://www.vvc.gov.lv/export/sites/default/docs/LRTA/Likumi/ Insolvency_Law.doc (most recently accessed on 24.3.2015). 
According to $\$ 4$ (3) of the Floating Charge Act ${ }^{* 16}$ of Estonia, the floating charge will be created after the corresponding entry is made in the floating-charge register. Section 2 (1) stipulates that the floating charge extends to all movable property of a company or movable property related to the economic activity of a sole proprietor. Section 2 (2) amends the above-mentioned and specifies that the floating charge extends to all encumbered property of an undertaking at the time the pledge entry is made and to the property acquired after the pledge entry is made. According to §2 (3), a floating charge does not extend to:

1) money in cash form or deposited with a credit institution; shares, stocks, investment-fund shares, contributions to co-operatives or participation in other companies belonging to an undertaking; promissory notes or other loan documents accepted in common usage; or other securities;

2) property that may be encumbered by a fixed charge, such as a possessory pledge or property that is encumbered by mortgage together with the immovable property with which it belongs to; or another type of pledge; or

3) property that, pursuant to the law, cannot be subject to execution.

Therefore, the floating charge covers almost all movable property of the debtor, with some minor exceptions. As the name 'floating charge' suggests and as described above, the object of the floating-charge assets fluctuates. In contrast, the objects of other charges are specified as certain properties or rights. The object of the floating charge shall finally be clarified in the process of the realisation of the floating charge, which is termed 'crystallisation,. ${ }^{* 17}$ In England, for example, the floating charge crystallises if a receiver is appointed for the debtor's company. ${ }^{*} 8$ Therein, the floating charge differs from other charges because of their object. In that case, the question arises of whether we have to treat the floating charge and other charges equally or not.

With respect to the difference, the floating charge encumbers all movable property of the debtor in its entirety, with the exception of certain minor assets. Consequently, the floating charge is regulated such that by covering the whole estate it causes other claims to be normally expected to remain fully unsatisfied. ${ }^{* 19}$ The resulting outcome is that in any insolvency proceedings wherein at least one floating-charge holder is present, unsecured creditors are not going to have the slightest motivation to participate and contribute to the insolvency proceedings. In fact, this means that one creditor is preferred to all other creditors in relation to the insolvent estate and causes unsecured creditors to be treated unfairly, thereby violating the principle of equal treatment of creditors.

The Cork Committee reached the conclusion that, to a limited extent, the general body of creditors should participate not like preferential creditors in priority to the holder of the floating charge but pari passu with him in the distribution of the proceeds from assets comprised in the charge. Such change may be expected to have the following beneficial consequences:

(a) by increasing the amount available in winding-up proceedings for the ordinary unsecured creditors, it should ensure a fairer distribution of the insolvent estate and encourage the ordinary creditors to play a fuller part in administration of the winding up.

(b) By increasing the dividends payable in the course of winding up to ordinary unsecured creditors, including trade suppliers, it should reduce the risk of further insolvency among them and discourage their increasing tendency to resort to reservation-of-title clauses and other devices to escape the priority of the floating charge. ${ }^{{ }^{2} 2}$

Consequently, the floating charge differs from other types of charges. The floating charge is fluctuating in nature and covers almost all movable property of the debtor, with only a few, minor exceptions. In the case of any other charge, the unsecured creditors are aware of the assets that are secured, while the case of the floating charge involves the unsecured creditors being unaware of the extent. The unawareness on the part of the unsecured creditors causes injustice and discourages the unsecured creditors from participation in the insolvency proceedings.

16 Kommertspandiseadus (Floating Charge Act). - RT I 1996, 45, 848 (in Estonian).

17 P. Varul et al. Asjaõigusseadus II. Kommenteeritud väljaanne (The Law of Property Act II: Commented Edition). Kirjastus Juura 2014, p. 371.

18 J. Duns. Insolvency Law and Policy. Oxford University Press 2002, p. 349.

19 Insolvency Law and Practice: Report of the Review Committee (see Note 11), p. 32.

$20 \quad$ Ibid., p. 32. 
In consideration of the above, the author finds that claims secured by a floating charge should be priority claims in the insolvency proceedings as other secured claims are but, because of the difference between the floating charge and other securities, the priority of the floating charge should be limited. Therefore, the floating charge needs special regulation applying to insolvency proceedings.

\section{Methods of limiting the priority of the floating charge}

The literature offers several opportunities for resolution of the issue of how to limit the priority of the floating charge in insolvency proceedings. For instance, the Cork Committee suggested a novel alternative to the existing regulation of the floating charge. In summary, the committee named $10 \%$ of the encumbered estate as 'a fund'. The idea of this fund is that a claim of a floating-charge holder is decreased by $10 \%$, where the gain is distributed among the so-called regular creditors. The Cork Committee proposed that the debenture-holder himself should not participate with the unsecured creditors in the $10 \%$ fund, but, to prevent the unsecured creditors doing better than the debenture-holder, the committee recommended that an upper limit be imposed so that the percentage of their debts received by the unsecured creditors should not in any event exceed that of the debenture-holder. ${ }^{{ }_{21}}$ The system would function in the manner described below.

Let us imagine that the assets encumbered by a floating charge were sold at the price of EUR 1,000,000, the claim secured by the floating charge is EUR 1,000,000, and the claims of the unsecured creditors come to EUR 200,000. Under the current law, the claim secured by the floating charge will be satisfied in the amount of EUR 1,000,000, which equals 100\% of its face value, and no monies will be paid out to the unsecured creditors. In contrast, in the case of the above-mentioned 10\%-fund system, the claims secured via the floating charge would be satisfied in the amount of EUR 900,000, or 90\% of their face value, while the amount of EUR 100,000 will be retained for distribution among the regular creditors. The claims of the latter will be satisfied in the amount of $50 \%$.

I would discuss how the so-called upper limit in the case of the $10 \%$-fund system would apply by giving the following example: Assets of the insolvent debtor have been sold for EUR 1,000,00o, the claim secured by the floating charge is EUR 2,000,000, and the claims of the unsecured creditors total EUR 100,000. Under the current law, the claim secured by the floating charge will be satisfied in the amount of EUR $1,000,000$, which makes up $50 \%$ of their face value, and the unsecured creditors will not have any monies to share among themselves, which means $0 \%$ of their claims' face value. In contrast, under the $10 \%$-fund system without upper limit, the unsecured creditors' claims will be satisfied in the amount of EUR 100,000, which comes to $100 \%$ of their face value, and the claim secured by the floating charge will be satisfied in the amount of EUR 900,000, or $45 \%$ of its face value. So without an upper-limit rule, unsecured creditors' claims will be satisfied in their full amount and the floating-charge holder will receive only $45 \%$ of their claim's face value. To avoid injustice here, the upper-limit rule applies, which means that the percentage of the unsecured claim being satisfied may not exceed the percentage of the secured claim satisfied. In that case, the claim of the floating-charge holder would be satisfied in the sum of EUR 952,381, which comes to $47.619 \%$ of the claim, and the claims of the regular creditors would be satisfied in the amount of EUR 47,619, which comes to the same $47.619 \%$ of the face value of the claim.

The Cork Committee argued that such a system would ensure fair pay-out from the insolvent estate and could also encourage unsecured creditors to participate actively in governing the process of insolvency. In addition, it has been argued that increasing pay-outs to the unsecured creditors helps them to remain in business themselves and also decreases the unfairness caused by the current ${ }^{* 22}$ floating-charge regulation under English law. ${ }^{* 3}$ The propositions of the Cork Committee were taken into account for changes to the insolvency law of England.

Beyond security claims, according to the insolvency law in effect in England, 'the order of priority of distribution of the monies available for the realisation of the assets is as follows:

(1) the cost and expenses of the liquidation, including the liquidator's own remuneration;

(2) preferential debts;

$21 \quad$ Ibid., p. 347.

22 Here, the committee report referred to the law that was valid at the time of the report's composition.

23 Insolvency Law and Practice: Report of the Review Committee (see Note 11), p. 347. 
(3) (if there is a floating charge relating to property of the company) the prescribed part of the company's net property, to be available for the satisfaction of ordinary, unsecured debts;

(4) debts secured by a floating charge (to be paid using the balance of the proceeds of realisation of the property comprised in the charge);

(5) ordinary, unsecured debts;

(6) post-insolvency interest on debts;

(7) deferred debts;

(8) the balance (if any), to be returned to the contributories." ${ }^{24}$

Professor Fletcher explains that "the definition of the "prescribed part" is based on a hypothetical construct, which involves the computation of the amount of the company's property (termed "the company's net property") which would, but for the provisions of [the Insolvency Act 1986's Section] 176A ${ }^{* 25}$ itself, be available for satisfaction of the claims of holders of debentures secured by, or holders of, any floating charge created by the company. ${ }^{*} 26$

Professor Fletcher continues: 'First, where the company's net property does not exceed $£ 10$ ooo in value, the prescribed part consists of 50 per cent of that property. Secondly, where the company's net property exceeds $£ 10000$ in value the prescribed part consists of the sum of two elements: 50 per cent of the first $£ 10000$ in value, and 20 per cent of that part of the company's net property which exceeds $£ 10000$ in value. However, an absolute maximum of $£ 600000$ is imposed on the total value of the prescribed part to be made available for the satisfaction of unsecured creditors in any given case. ${ }^{*}{ }^{27}$

Professor Fletcher has found that 'the purpose of this regulation is to adjust the distribution of corporate assets on insolvency, so that a portion of the assets comprised in any floating charge granted by the company is made available to the satisfaction of the unsecured creditors. ${ }^{\prime}{ }^{2} 8$

In the author's opinion, it is clear that these amendments made to the English Insolvency Act are composed on the basis of methods quite similar to those outlined by the Cork Committee. The system of limiting the priority of the floating charge in the insolvency proceedings worked out by the Cork Committee and the system used in the Insolvency Act of England in force today are both based on rather excellent ideas, except that these systems are too complicated to implement.

For instance, Finnish law too appears to be affected by the ideas of the Cork Committee report, because the floating charge is not fully preferred in Finnish insolvency proceedings. However, the way that Finnish law regulates the priority of the floating charge in insolvency proceedings is much simpler. According to Article 5 of the legal act addressing priority claims ${ }^{* 29}$, the claims of holders of a floating charge are secured only in the amount of $50 \%$ of the value of the encumbered assets.

\section{The system of limitation of the priority of the floating charge}

The author agrees with the Cork Committee to the extent that allocation of a certain amount from the funds originally meant to be distributed to the floating-charge holder, on behalf of the unsecured creditors, will relieve injustice and motivate unsecured creditors to take part of the insolvency proceedings. However, the author is of the opinion that the $10 \%$ fund proposed by the Cork Committee is too complicated in implementation. That said, the methods proposed in the report are necessary for composition of a fair system for determining the amount to be distributed to the unsecured creditors on behalf of the floating-charge holder.

Considering the discussion above, the author supports creation of a system for distributing a fair amount of money to the unsecured creditors on behalf of the floating-charge holder's fund. Although the

24 I.F. Fletcher. The Law of Insolvency. London: Sweet \& Maxwell 2009, p. 773.

25 Insolvency Act 1986. Available at http://www.legislation.gov.uk/ukpga/1986/45/contents (most recently accessed on 21.3.2015).

26 I.F. Fletcher (see Note 24), p. 787.

27 Ibid., p. 788.

28 Ibid., p. 787.

29 Laki velkojien maksunsaantijärjestyksestä (Act on the Ranking of Claims). Available at http://www.finlex.fi/fi/laki/ajantasa/1992/19921578 (most recently accessed on 21.3.2015) (in Finnish). 
floating-charge holder is a secured creditor, this intervention in the rights of the floating-charge holder is justified - if its extent remains minimal - because of the principle that security interests and other real rights created prior to the insolvency proceedings are unaffected by the winding up. Therefore, the system for distributing a fair amount of money to the unsecured creditors on behalf of the floating-charge holder's fund should be as simple as possible and limit the rights of the floating-charge holder only to the minimal limit necessary on the one hand, and to relieve injustice and encourage the unsecured creditors to participate in the insolvency proceedings on the other hand.

In consideration of the above, the author proposes the following solution. The claims secured by the floating charge would be preferred to a certain extent only, and in the remaining part such claims should participate in the distribution to the unsecured creditors in accordance with the pari passu principle. This solution guarantees that in a certain amount the floating-charge holder will be preferred and in the remaining amount the claim that was secured by the floating charge shall not go unsatisfied but participate in the distribution of the remaining funds on equal ground with the unsecured creditors, according to the pari passu principle. This system enables regulation of the extent of the priority accorded the floating-charge holder by percentage and secures a particular fund for the unsecured creditors. In any case, if there are funds to be distributed, the floating-charge holder will receive more than unsecured creditors and unsecured creditors will not remain fully unsatisfied. The determination of the exact percentage indicating the extent to which the floating-charge holder should be preferred is up to every jurisdiction. The author would recommend limiting the priority of the claim secured by the floating charge to $50 \%$.

For example, if the claims secured by the floating charge were to be preferred in the extent of $50 \%$, the situation would be as follows. Let us take a case wherein the assets of the insolvent debtor have been sold for EUR 1,000,000, the amount of the claims secured by the floating charge is EUR 1,000,000, and the claims of the regular creditors amount to EUR 300,000. Current Estonian law provides for the satisfaction of the claim of the floating-charge holder in its entirety and the regular creditors have nothing to receive.

In contrast, under the system the author proposes, the claims secured by the floating charge are preferred in the amount of EUR 500,000, or 50\%. Next, the remaining EUR 500,000 is to be shared pari passu among the regular creditors and the floating-charge holder to the extent that his claim remained unsatisfied. In consequence, the second-rank claim of the floating-charge holder is satisfied in the amount of EUR 312,500 (that is, $62.5 \%$ of EUR 500,000) and the so-called regular creditors receive EUR 187,500, which is $37.5 \%$ of EUR 500,000. In summary, the floating-charge holder receives EUR 500,000 plus EUR 312,500 , which totals $81.25 \%$ of the claims. The regular creditors' claims are satisfied in the amount of EUR 187,500 , or $62.5 \%$ of their face value. Such an outcome is much more acceptable to the regular creditors and, at the same time, does not decrease the floating-charge holder's dividend significantly.

Proceeding from the foregoing, the author maintains that the claims secured by the floating charge should be preferred to a certain extent only. In the remaining part, such claims should participate in the distribution to the unsecured creditors in line with the pari passu principle. Taking into consideration the Finnish law, the author finds that it is reasonable to prefer the floating charge only in the amount of $50 \%$ of the outcome. In the remaining part, such claims must be treated with unsecured claims in accordance with the pari passu principle.

\section{Conclusions}

The author has reasoned in this article that secured creditors should have priority in insolvency proceedings. If the security were to be void in the event of insolvency, the risk of unsuccessful investments in the case of insolvency becomes higher for the creditor. The greater risk of losing the invested amounts leads to higher interest rates and a reduction in loans. Accordingly, creditors will invest more funds if their loans are secured in case of the insolvency of the debtor than if their loans are not secured in case of the debtor's insolvency. Securing the claim induces creditors to invest more funds, which encourages the credit system. The credit system is important for the development of the market economy. Thus, the protection of securities in the insolvency proceedings develops the economy, which is the reason for which the securityassociated claims shall be preferred in insolvency proceedings.

The floating charge is a security and, accordingly, shall be preferred in insolvency proceedings. Still, the floating charge differs from other securities - because of its object. If a loan is secured by a pledge, the 
lender and the borrower know that, whatever happens, the object of the loan shall secure the loan. This means that if the borrower does not pay, the object of the pledge shall be sold and the outcome shall cover the loan. In regular cases, the creditor and the debtor know exactly what object is pledged. Only in the case of the floating charge shall the object of the pledge become known after crystallisation. This means that the object of the floating charge is not certain; as the name indicates, the object is floating. Generally, the object of the floating charge includes all of the movable property that is not secured by other pledges, with some exceptions (money, stocks, etc.). In the case of the floating charge having full priority in insolvency proceedings, the outcome of the process of selling the property of the insolvent debtor shall be distributed only to the floating-charge holder whilst the claims of the unsecured creditors remain unsatisfied. A situation wherein the claims of the unsecured creditors go unsatisfied distinctly decreases the interests of the unsecured creditors in participating in the insolvency proceedings and inflicts inequality. Full priority of the floating charge in the insolvency proceedings so as to leave the unsecured creditors without dividends is strictly against the principle of collective proceedings and the principle of the equal treatment of creditors in the course of insolvency proceedings.

Whereas the nature of the floating charge differs from that of other securities, special regulation of the floating charge is necessary for insolvency proceedings. In order to relieve injustice and motivate the unsecured creditors to take part in the insolvency proceedings, one should limit the full priority of the floating charge in the insolvency proceedings such that a certain amount from the funds generated via the sale of the property secured by the floating charge shall be distributed to the unsecured creditors.

The author suggests a system wherein the floating charge would be preferred to a certain extent only and in the remaining part such claims should participate in the distribution to the unsecured creditors in accordance with the pari passu principle.

The exact percentage is a matter for further discussion. The author considers it reasonable that 50\% of the amount of the claim secured by the floating charge be regarded as a secured claim. The remaining amount can participate in distribution of dividends equally with the unsecured creditors' claims in line with the pari passu principle.

This system does not infringe the rights of the floating-charge holder significantly, yet it relieves injustice and increases the degree of participation of unsecured creditors in insolvency proceedings. 